\title{
LA VISUALIZACIÓN DE LA MÚSICA EN EL VIDEOCLIP
}

\author{
David Selva Ruiz \\ (Universidad de Cádiz) \\ david.selva@uca.es
}

\begin{abstract}
Resumen: : La imagen y la música son los dos componentes fundamentales del videoclip. Aunque los estudios han tendido a centrarse en los aspectos visuales y a obviar el componente musical, lo cierto es que la música existe con anterioridad a la imagen del videoclip y, en consecuencia, determina la concepción y construcción de ésta, máxime teniendo en cuenta la función del videoclip como herramienta de comunicación comercial específica del sector fonográfico. Se estudia, pues, la interacción entre la música y la imagen a partir del concepto de sinestesia, y, en concreto, la influencia de los diversos elementos musicales de cara a la construcción formal del videoclip.
\end{abstract}

Palabras clave: videoclip, música, imagen, sinestesia, comunicación.

Abstract: Image and music are the two fundamental components of music video. Although studies have tended to focus on the visual aspects and ignore the musical component, music exists prior to the music video image and, consequently, determines its conception and construction, especially considering the role of music video as a communication tool for the phonographic industry. Therefore, the interaction between music and image is studied through the concept of synesthesia, and, in particular, the influence of musical elements on the formal construction of music video.

Keywords: music video, music, image, synesthesia, communication.

\section{INTRODUCCIÓN.}

esulta muy frecuente que los estudios sobre el videoclip señalen la existencia de una estética visual propia. Esta cuestión suele ser estudiada mayoritariamente por aquellos autores que proceden del ámbito de los estudios fílmicos o de las teorías posmodernas. En ambos casos, "el problema es que los videoclips musicales, al igual que los servicios de televisión musical como MTV, son estudiados de forma aislada respecto a la propia música, y prestando muy poca atención hacia sus importantes raíces en la industria musical" (Goodwin, 1992: 3 /1TP ).

En el caso de los estudios fílmicos, es frecuente que las teorías sobre el cine eviten referirse al sonido, lo dejen de lado o lo consideren como algo menor, ignorando las interrelaciones existentes entre música e imagen (Chion, 1993: 11). En el caso de las teorías posmodernas, su estudio se centra en la identificación del videoclip como un arquetipo de texto posmoderno que vendría a demostrar las 
propias teorías preexistentes. Así, diversos autores caracterizan el videoclip como ejemplo perfecto de todo aquello que califican de "estética posmoderna": triunfo de los significantes sobre los significados, estética del fragmento, intertextualidad y pastiche, autorreferencialidad, banalización de lo ideológico, etc. (Aufderheide, 1986; Fiske, 1984; 1986; 1997; Kaplan, 1989; Tetzlaff, 1986).

El problema fundamental de estos planteamientos es que suelen partir de la existencia de unos determinados parámetros formales o estéticos universales no siempre justificados. Por ejemplo, Gilles Lipovetsky explica: "No se trata de evocar un universo irreal o de ilustrar un texto musical, se trata de sobreexcitar el desfile de imágenes y cambiar por cambiar, cada vez más rápido y cada vez con más imprevisibilidad y combinaciones arbitrarias y extravagantes" (1990: 240). Este autor enmarca el videoclip en la "cultura express" actual, y en ella encuentra la explicación a sus parámetros estéticos. Sin embargo, como diversos investigadores se han encargado de señalar, el alto número de planos no implica "cambiar por cambiar", ni sus combinaciones son siempre arbitrarias; y, sobre todo, no existe una única y cerrada "estética del videoclip", ya que, "por cada vídeo que exhibe una estética 'posmoderna', hay otro vídeo construido sobre una narrativa más clásica o una estética romántica" (Grossberg, 1993: 187 / TP).

Autores como Goodwin o Leguizamón aportan la explicación más convincente a esta cuestión. Para este último, el hecho de que no todas las músicas sean frenéticas o fragmentarias implica que no todos los videoclips van tampoco a serlo, ya que la música es anterior a la imagen en la creación de un videoclip $y$, por tanto, condiciona sus aspectos formales (1998). Parece razonable que la estética visual sea muy diferente en Smack My Bitch Up, de Prodigy, y Nothing Compares $2 U$, de Sinéad O'Connor; de hecho, lo extraño sería que, ante temas musicales tan diferentes, la plasmación visual de los mismos fuera semejante. Como señala Hayward, "el extenso campo del videoclip abarca una diversidad tan grande de textos y estilos individuales que resiste las grandes generalizaciones" (1990: 126 / TP).

No en vano, la música es un elemento fundamental en el videoclip, en tanto que elemento original y determinante en la elaboración de éste. Sin embargo, como se ha dicho, es frecuente que los investigadores obvien que la música, junto con otros factores, determina la creación del aspecto visual, hasta el punto de que la canción puede existir sin imágenes, pero las imágenes del videoclip no suelen tener sentido sin la canción. Como señala Sedeño Valdellós:

El elemento icónico del videoclip es creado a partir de la elección de una canción (normalmente emblemática del disco que quiere promocionarse), que marca su 
duración y su ritmo o tempo, tanto del cambio visual como del ritmo interno, a través de una selección cuidadosa de las transiciones para sincronizarlas con la melodía y el ritmo (2002: 62).

Igualmente, la música condiciona también la iconografía de la imagen (Goodwin, 1992: 56). Resulta conveniente partir de la idea de que las imágenes del videoclip buscan servir como un refuerzo y una aportación a la música, por lo que no se pretende restar protagonismo a las interpretaciones de los artistas musicales (Gow, 1992: 65). En cualquier caso, el papel condicionante de la música es incluso aceptado por autores que estudian el videoclip basándose fundamentalmente en la imagen. Así, Kaplan explica que "habitualmente la canción es escrita primero, y por eso toma prioridad sobre las imágenes, limitando las posibilidades visuales. La creatividad del director debe estar subordinada a la del compositor y el intérprete" (1989: 14 / TP). No obstante, la centralidad de la música no se halla únicamente en su carácter original, sino también en la finalidad promocional del videoclip, la cual convierte el análisis de la relación entre música e imagen en algo necesario, asumiendo que lo visual supone un apoyo para, entre otras cosas, estimular el atractivo de lo sonoro a los ojos del espectador (Goodwin, 1992: 70).

Con este punto de partida, se va a analizar la relación entre la música y la imagen en el videoclip. Se parte de una fundamentación teórica de la interacción entre estos dos componentes a partir del concepto de sinestesia, y, posteriormente, se estudia el papel jugado por los distintos elementos musicales en la construcción formal del videoclip.

\section{LA INTERACCIÓN ENTRE MÚSICA E IMAGEN}

Debe explorarse, pues, la relación entre música e imagen con la finalidad de descubrir las formas de interacción entre ambas. Hay que partir de que la música genera reacciones muy diversas en el público:

Las audiencias participan en la música popular de formas que son físicas (cantando a la par, chasqueando, aplaudiendo, bailando, con excitación sexual, etc.); emocionales ("sintiendo" la música, rememorando, idealizando, consiguiendo un "clímax" espiritual, etc.); y cognitivas (procesando información, aprendiendo, estimulando el pensamiento, contribuyendo a la memoria, elaborando percepciones, etc.) (Lull, 1992: 19 / TP).

Por tanto, difícilmente se puede analizar la música $-\mathrm{y}$, en consecuencia, el videoclip - atendiendo únicamente a su dimensión cognitiva. De hecho, como apuntan diversos autores, uno de los aspectos más llamativos de la música es su capacidad para expresar emociones y generar efectos emocionales en el público. Como explica Bruner II, los seres humanos asignan significado emocional

\footnotetext{
${ }^{1}$ A lo largo de todo todo el presente trabajo, se emplea la abreviatura TP ("Traducción Propia") para indicar que una cita textual ha sido traducida al castellano por el propio autor.
} 
a la música y experimentan reacciones afectivas a la música (1990: 99). Alan Wells $(1990 ; 1991)$ ha investigado los aspectos emocionales de la música y su recepción, y sus conclusiones apuntan claramente a la existencia de un significado emocional profundo que no sólo se encuentra en las letras, sino también en el sonido o la música. En muchos casos, las personas asocian la música con experiencias personales - como los amores actuales o pasados-, y es empleada por ellas para incidir sobre sus propios estados de ánimo y sus emociones. En otras palabras, "no es sólo ruido o entretenimiento, sino una psicoterapia autoadministrada que funciona" (1990: 116 / TP). En realidad, es algo que cualquier persona conoce y administra, incluso de forma inconsciente. Por ejemplo, se eligen diferentes músicas para acompañar una fiesta con amigos, un encuentro romántico, una sesión de aerobic, una boda, un funeral, un discurso solemne, etc. Esto no quiere decir que los significados de la música no sean, en la mayoría de casos, una cuestión de percepción completamente personal; es decir, la canción puede no tener un significado referencial intrínseco, pero sí generar significados en el público (Cubitt, 2000: 150-151; Robinson, 1986: 46). Sintetizando, puede decirse que, en cualquiera de los casos, la música constituye "una secuencia de pensamientos y sentimientos apasionados que expresan significado de un modo que no tiene paralelo en la vida humana" (Lull, 1992: 1 / TP).

Esto se acentúa en el ámbito de la música popular. Aunque la canción tenga una raíz industrial, tiene indiscutiblemente un significado para el público: "Por muy cínico que resulte el artificio de la génesis industrial de un disco de éxito, las emociones que evoca son indudablemente reales: lágrimas reales, excitación real, relajación real. Son reacciones fisiológicas virtualmente medibles" (Cubitt, 2000: 142 / TP). Como señala Pérez-Yarza, la música popular llega al receptor a un nivel más somático que cognitivo, al contrario de lo que sucede, por ejemplo, con la música clásica (1996: 6). Esto provoca que el videoclip trate de reflejar las sensaciones orgánicas que la música crea en el receptor. Así, Leguizamón se pregunta:

\footnotetext{
¿Acaso cada uno no hace sus propios clips de la música preferida? Muchas veces hubiéramos querido poder grabar todo lo que pudimos captar o imaginar al escuchar esa canción [...], como también los sueños, los recuerdos, el deseo. Ello es natural: el mundo en trazos de rostros, cromas, formas, ideas fugaces, palabras, diálogos interrumpidos y extraños conocidos (1998).
}

No cabe esperar, por tanto, una gran coherencia interna en los videoclips, ya que, como se ha dicho, "a modo de puzzle tratan de recomponer un todo, reflejar un estado emocional y en menor medida, ordenar una serie de acontecimientos en el tiempo" (Pérez-Yarza, 1997: 355-356). El videoclip refleja formalmente aquello que es evocado o imaginado por la propia música. Por esta razón, del mismo modo que la musicología actual intenta comprender cómo "siente" la canción pop (McClary \& Walser, 1990: 288-289), el estudio del videoclip debe ir más allá y explicar cómo esos "sentimientos" contenidos en la música son recogidos por las imágenes de este formato audiovisual. 
Ya en 1808, Ludwig van Beethoven, en los apuntes a sus obras, hacía referencia a la capacidad de la música para evocar imágenes. Es el caso de la Sexta sinfonía, conocida como Pastoral por el subtítulo de "recuerdo de la vida campestre", la cual cuenta con movimientos como "Despertar de apacibles sentimientos al llegar al campo", "Escena junto al arroyo" o "Alegre reunión de campesinos". Esto es un ejemplo de lo que Auserón llama "imagen sonora", concepto con el que trata de explicar cómo el sonido, sea verbal o musical, mimetiza imágenes (1998: 15). Este proceso es inverso en el caso del videoclip, ya que son los sonidos los que se convierten en imágenes durante el proceso de creación de un videoclip. En ambos casos, este fenómeno puede explicarse a través del concepto de sinestesia.

La sinestesia es, como fenómeno psicológico, una "imagen o sensación subjetiva, propia de un sentido, determinada por otra sensación que afecta a un sentido diferente" (RAE, 2003). Supone, pues, un "proceso intrapersonal por el que unas impresiones sensoriales son trasladadas de un sentido a otro" (Goodwin, 1992: 50 / TP). Este fenómeno, que puede considerarse la base perceptual del videoclip, implica, por ejemplo, ver sonidos, probar olores y oír colores (Dickinson, 2007: 14; Williams, 2003: 11). Así, los sonidos tienen la capacidad de generar un efecto más allá del sentido del oído, provocando que, durante la recepción de la música, se evoquen, entre otras, sensaciones propias del sentido de la vista, como demuestran empíricamente diversos estudios, como los de Osborne (1981), Quittner y Glueckauf (1983), y Abt (1987). Este proceso tiene lugar tanto en los oyentes como en los músicos y realizadores de videoclips. Así, la creación de un videoclip implicaría trasladar a imágenes las sensaciones que provoca el sonido².

No en vano, Goodwin observa que existe un alto grado de consenso en la evocación de determinados sentimientos, estados de ánimo e imágenes por parte de la música (1992: 55)33. Esto no quiere decir que la creación de un videoclip constituya un trabajo de denotación; al contrario, se trata de un fenómeno fundamentalmente subjetivo, basado en la connotación, y en el que el trabajo creativo del realizador juega un importante papel (Pérez-Yarza, 1997: 85).

En otras palabras, el videoclip no se limita a ofrecer al público las imágenes que este mismo habría imaginado escuchando una canción, sino que va más allá (Rubey, 1992: 245). Como explica Goodwin, el videoclip no se reduce a una mera traducción visual de los elementos musicales, ya que existe una cierta autonomía del videoclip respecto a la canción, que, aunque relativa y limitada, se plasma en diversos aspectos:

a) la visualización de la canción puede ir más allá del significado de la canción; b) el formato busca aportar placer al espectador para que permanezca pegado a la pantalla y, en su caso, pueda ver repetidamente un mismo videoclip; c) en ocasiones, los videoclips promocionan otros productos diferentes a los puramente musicales; y d) los videoclips desarrollan imágenes del artista y su personalidad que pueden exceder cualquier canción individual (1992: 85). Además, como explica Gow, las imágenes del videoclip pueden destacar sentimientos y emociones 
particulares dentro del amplio campo de posibilidades afectivas que lleva aparejado una canción (1994). En cualquier caso, no debe perderse de vista que "el placer de un videoclip proviene de captar una forma de sentir [...] y representarla en un nuevo contexto" (Vernallis, 2004: 116 / TP).

Estos planteamientos son corroborados por los propios creadores, como el director Spike Jonze, quien afirma: "Todos mis vídeos han nacido del sentimiento que me ha provocado una canción" (en Fernández-Santos, 2004: 37). Sin embargo, debe tenerse presente que la autoría del videoclip se ve condicionada por otros agentes, como el director artístico (A\&R) de la empresa fonográfica o los propios músicos. En este sentido, las compañías, en tanto que financiadoras del videoclip, suelen imponer límites a la creatividad de los realizadores y demandar una prioridad de las imágenes del cantante sobre otras menos referenciales; y los músicos, especialmente cuando son también compositores, tienen también sus propias ideas y propuestas respecto al videoclip. Bono, vocalista de U2, explica:

Yo siempre tengo imágenes visuales en mente cuando escribo letras. La mayoría de nuestras canciones tienen unas imágenes muy cinemáticas. Creo que la mayoría de bandas probablemente escriben canciones con las imágenes en mente. En las letras, estás normalmente describiendo cosas, imágenes mentales. No es un salto muy grande visualizarlas realmente (en Shore, 1984: 237 / TP).

Lógicamente, si el previo proceso de creación de la canción puede implicar la conversión de unas ideas en sonidos, los músicos pueden demandar que, a la inversa, aquellas ideas sean tenidas en cuenta.

Los planteamientos de Goodwin (1992), quien sostiene, como este trabajo, que la música es prioritaria en el videoclip, han sido criticados implícita o explícitamente por algunos autores. Williams (2003) no critica a Goodwin, aunque sí sostiene que, al igual que no tiene sentido destacar lo visual sobre el sonido, tampoco el sonido debe destacarse sobre lo visual: "celebrar meramente lo auditivo frente a lo visual [...] no se ocupa satisfactoriamente del videoclip. Lo visual es radicalmente importante" (2003: 12 / TP). El autor propone, pues, que las imágenes y los sonidos se interpenetran entre sí de un modo que crean una tercera dimensión expresiva que llama "visualidad musical", a través de la cual "las imágenes bailan con los sonidos de la música y los sonidos aparecen visualmente" (2003: 100 / TP). Gow opina en un sentido parecido cuando afirma que los investigadores han tendido a acentuar la música o la imagen, dejando de lado la evidente relación sinérgica que tiene lugar entre ambos componentes del videoclip. Así, el autor critica explícitamente a autores como Kaplan o Jones por centrarse en la imagen y a Goodwin o Frith por centrarse en la música y, desde su punto de vista, relegar las imágenes a un rol meramente ilustrativo o amplificador (1994: 256-257). La posición de Dickinson es similar a la de Gow, ya que rechaza explícitamente las posiciones de Goodwin por acentuar la importancia de la música, y explica la importancia de la sinergia de los distintos componentes del videoclip, que, en el videoclip, acaban por fundirse y confundirse hasta crear un todo en el que el significado aportado por los distintos integrantes es difícil 
o imposible de aislar (2007: 14-15). Se está completamente de acuerdo con las opiniones de Williams, Gow o Dickinson respecto a que ambos integrantes -música e imagen- se combinan en el videoclip para dar lugar a un todo mayor que la suma de las partes. Sin embargo, no se considera que las posiciones de Goodwin, que simplemente plantea la prioridad de la música tanto en un plano temporal -es preexistente respecto a la imagen -como funcional- en tanto que producto promocionado-, sean incompatibles con las de estos autores. Es cierto que el autor pone mucho énfasis en reforzar la importancia de la música en el videoclip, si bien debe entenderse el contexto académico de su libro.

Los primeros años del videoclip -o, más bien, de MTV- vinieron acompañados de abundante investigación académica por parte de teóricos posmodernos o de investigadores próximos a los estudios fílmicos, los cuales solían dejar la música a un lado para dedicar toda su atención a la imagen. Por tanto, puede entenderse el énfasis de Goodwin, no como un deseo de despreciar la imagen, sino como una pretensión de rebatir el frecuente olvido de la música en el videoclip. Por tanto, poniendo paz en esta polémica, puede concluirse que la música es el punto de partida en el ámbito de la creación del videoclip y que música e imagen operan de forma conjunta y sinérgica en el ámbito de la recepción.

\section{LOS ELEMENTOS MUSICALES Y LA CONSTRUCCIÓN DEL VIDEOCLIP}

La mayoría de trabajos acerca de los aspectos formales del videoclip suele partir de las teorías de la imagen. Como resultado, existen estudios de notable interés que describen y analizan el empleo de los distintos elementos visuales que conforman este formato. Sin embargo, como ya se ha señalado, las imágenes son añadidas con posterioridad a una canción preexistente y, por tanto, están subordinadas a ésta. Aunque no puede negarse la existencia de una serie de recursos visuales y narrativos que se presentan con gran frecuencia, deben explicarse las razones de su empleo. De lo contrario, se caería en tópicos como el de la existencia de una "estética del videoclip", que tipifica en exceso el De lo contrario, se caería en tópicos como el de la existencia de una "estética del videoclip", que tipifica en exceso el complejo universo de este formato. Por esta razón, Goodwin propone estudiar los distintos aspectos icónicos presentes en el

\footnotetext{
${ }^{2}$ Curiosamente, el sonido y, en consecuencia, la música son visuales en su representación digital y, además, la manipulación del sonido en la música actual tiene lugar de forma similar a la de la imagen: cortando, pegando, etc. (Jones, 1999).

${ }^{3}$ En sentido estricto, la sinestesia hace referencia a la evocación de realidades sensibles inalterables -colores, olores, etc.- , por lo que, aunque se reconozca la existencia de otro tipo de relaciones -intertextuales, psicológicas, onomatopéyicas, etc.-, éstas no implicarían una relación sinestésica en sentido estricto (Gértrudix Barrio, 2003: 46). Como puede verse, en este trabajo se parte de una concepción amplia del fenómeno de la sinestesia, muy semejante a la empleada por Goodwin (1992).
} 
videoclip a partir de los elementos musicales (1992: 50). Su estudio podría permitir una mayor comprensión del montaje del videoclip que, lejos de estar injustificado, constituye la herramienta básica para que el realizador consiga la conexión de la imagen con la música (Frith, 1988: 219).

Como explica Darley, los videoclips utilizan nuevas técnicas de producción y manipulación de imágenes para producir formas innovadoras de visualizar la música. En otras palabras, la velocidad y el ritmo de la combinación de imágenes, los ciclos y las repeticiones (reiteradas y variadas) acumulativas, se encuentran determinadas por la estructura de la canción y por elementos formales como la melodía, el ritmo y el tempo (2002: 187).

Hay que tener en cuenta que elementos como la melodía, el ritmo y el tempo tienen, además, una serie de consecuencias emocionales en el público. Por ejemplo, en la figura 1 puede observarse la conexión entre seis de aquéllos y una serie de expresiones emocionales diversas. De un modo similar al de la música, las técnicas de cámara y edición llevan asimismo aparejadas determinadas reacciones emocionales, por lo que cabe esperar una conexión entre la música y la imagen también a este nivel. No obstante, esto no debe confundirse con la existencia de unas reglas estrictas de conversión de la música en recursos visuales, ya que estos variarán notablemente en cada caso concreto (Armer, 1990: 344, 348). Aunque las imágenes del videoclip partan de la música, el trabajo del director tiene un carácter fundamentalmente creativo y, en consecuencia, no se trata de un mero trabajo de traducción visual o un ejercicio puramente técnico.

Figura 1. Caracteristicas musicales para producir diversas expresiones emocionales

\begin{tabular}{|c|c|c|c|c|c|c|c|c|c|}
\hline & \multicolumn{7}{|c|}{ Expresín emocional } \\
\hline $\begin{array}{c}\text { Elemento } \\
\text { musical }\end{array}$ & Serio & Triste & Sentimental & Sereno & Humoristico & Feliz & Excitante & Majestuoso & Terrorifico \\
\hline Modo & Mayor & Menor & Menor & Mayor & Mayor & Mayor & Mayor & Mayor & Menor \\
\hline Tempo & Lento & Lento & Lento & Lento & Rápido & Rápido & Rápido & Medio & Lento \\
\hline Tono & Bajo & Bajo & Medio & Medio & Alto & Alto & Medio & Medio & Bajo \\
\hline Ritmo & Firme & Firme & Fluido & Fluido & Fluido & Fluido & Irregular & Firme & Irregular \\
\hline Armonia & Consonante & Disonante & Consonante & Consonante & Consonante & Consonante & Disonante & Disonante & Disonante \\
\hline Volumen & Medio & Bajo & Bajo & Bajo & Medio & Medio & Alto & Alto & Variado \\
\hline
\end{tabular}

Fuente: Bruner II (1990: 100/TP)

De cara al estudio de la relación entre los elementos musicales y la construcción del videoclip, puede partirse de la clasificación empleada por Aaron Copland, que contempla cuatro elementos musicales básicos: el ritmo, la melodía, la armonía y el timbre (1972).

En primer lugar, estaría el ritmo. Entre los diversos elementos musicales, la mayoría de los teóricos se centran este elemento -si bien algunos lo confunden con el tempo-. Éste se entiende como la ordenación de los sonidos en el tiempo, con toda la complejidad que ello conlleva. Gértrudix Barrio lo define del siguiente modo: "Combinación de las duraciones, pulsos e intensidades de los sonidos. 
Se rige por las leyes de la periodicidad" (2003: 65). Lógicamente, el ritmo de la canción condiciona el de las imágenes, y la evolución y los cambios de aquél a lo largo de la duración de la canción permiten asimismo la evolución del videoclip en su conjunto (Gaskell, 2004: 52). Además, no hay que olvidar las implicaciones culturales de los distintos ritmos, que raramente se ven analizados desde el ámbito académico. Sin embargo, un ritmo de reggaeton o de tango nos conduce mentalmente a lugares y situaciones específicas. En cualquier caso, según Chion, la relación fundamental entre sonido e imagen tiene lugar por la presencia de una serie de puntos en los que se produce la unión entre ambos componentes de forma momentánea. Desde su punto de vista, el videoclip es una combinación de sincronización y desincronización, ya que coexisten "unos p.d.s. [puntos de sincronización] extremadamente nítidos, en los cuales la relación de sincronismo está muy afirmada, con una muy elevada desincronización en otros instantes y una libertad total de los movimientos de la imagen en relación con el sonido" (1993: 157).

La sincronía se manifiesta en el videoclip a través de aspectos relacionados con la edición, es decir, cortes de plano, transiciones, etc. No obstante, la sincronización no sólo se muestra a través de la edición, ya que también existe sincronía cuando el cantante o la banda aparecen interpretando el tema musical —en el caso de una banda, cada integrante con su instrumento musical, incluido el vocalista-, alguien realiza un gesto al ritmo de la música, o se muestra cualquier tipo de baile (Leguizamón, 1998; Sedeño Valdellós, 2002: 48). Goodwin explica que estas formas de movimiento profílmico protagonizadas por los propios artistas, por bailarines, etc. tienen también como objetivo visualizar la música (1992: 69). Por ejemplo, en Faith, de George Michael, la boca del cantante y sus movimientos con el pie son elementos clave para representar el ritmo de la canción. De hecho, según Pérez-Yarza, la complejidad narrativa del videoclip, donde no es necesario un orden temporal o espacial, encuentra su anclaje básico en los labios, los instrumentos o los gestos de los músicos (1997: 356) y, cabe añadir, de cualquier otra persona que intervenga en el videoclip. Además, gracias a estos puntos de sincronización -y de anclaje-, el espectador tiende a identificar la imagen como la fuente real del sonido, aun cuando éste suele tener, en la inmensa mayoría de las ocasiones, origen extradiegético (Ràfols \& Colomer, 2006: 34).

Como plantea Vernallis, los teóricos suelen reducir la relación entre música e imagen a estas correspondencias rítmicas, especialmente a través del cut on the beat, es decir, los cortes de plano al compás de la música (2004: 44). Este aspecto es frecuente en videoclips como The Hardest Button to Button, de The White Stripes, el comienzo de Small Town, de John Mellencamp, o el final de Desire, de U2. Sin embargo, debe tenerse presente que las canciones que sirven de base a estos videoclips tienen un ritmo muy marcado. No en vano, los videoclips realizados para canciones con un ritmo menos acentuado, como Lo echamos a suertes, de Ella Baila Sola, o Siete vidas, de Antonio Flores, conceden escasa o nula importancia al corte de plano sincrónico.Rafòls y Colomer explican esta y otras diferencias entre una música de base rítmica y una de base melódica: 
La música de base rítmica y de percusión rápida crea una fuerte tensión y reclama mucho movimiento de elementos diferentes. La música de base melódica con notas largas sin demasiados cambios y sin percusión reclama movimientos más suaves, una imagen de mayores matices y unos colores poco saturados (2006: 35).

Una visión similar muestran Vernallis (2004: 50) y Armer, quien recomienda emplear el cut on the beat en las canciones con un tempo rápido, ya que esta técnica tiene como consecuencia que "una secuencia de cortes (cada dos compases, cada cuatro compases) casi pasa a formar parte de la música" (1990: 349 / TP). En cualquier caso, Goodwin señala, volviendo a la idea de la combinación de sincronización y desincronización, que los cortes son más frecuentes fuera de los tiempos fuertes del compás que sobre ellos incluso en los videoclips con un ritmo más marcado y un tempo rápido, y argumenta que el ritmo de la canción es, de hecho, el elemento musical menos importante en el videoclip (1992: 62-63). Puede concluirse, por una parte, que aunque el ritmo puede tener una notable influencia sobre el videoclip, ésta es menos intensa de lo planteado por otros autores; $y$, por otra, que, incluso cuando el ritmo de la canción se ve reflejado en el videoclip, el cut on the beat no es, ni mucho menos, la forma generalizada de representarlo, sino que, más al contrario, su empleo suele reducirse a fragmentos y momentos concretos. Por ejemplo, la forma de representar el marcado ritmo de la canción en el citado Technologic, de Daft Punk, no es el cut on the beat, sino la aparición de palabras de la letra — que constituye la base del ritmo en esta canción- en un monitor al compás de la música.

Más importancia tendría "la velocidad del ritmo" (Shuker, 2005: 218), esto es, el tempo. Como señala Vernallis, el videoclip tiende a subrayar los aspectos más llamativos de la canción, por lo que si ésta tiene un tempo rápido o lento, la imagen suele reflejarlo o, incluso, superarlo (2004: 49). Por ejemplo, puede compararse el uso del morphing aplicado a una serie de rostros humanos que llevan a cabo Cry, de Godley \& Creme, y Black or White, de Michael Jackson; la velocidad de este empleo en uno y otro no es más que un reflejo de la velocidad de la canción. Según Goodwin, gran parte de los recursos propios del videoclip son empleados para visualizar la velocidad de la canción, como los movimientos de cámara, el alto ritmo de montaje, el movimiento profílmico o los efectos de posproducción. Por ejemplo, a nadie le extraña que el baile de Fred Astaire en una película musical sea más acelerado con una canción animada y divertida que con una lenta y romántica. Así, tampoco debería hacerlo la existencia de gran movimiento profílmico o el uso del corte rápido, presente en la mayoría de videoclips, ya que "cortar a la velocidad del cine o la emisión televisiva parecería incongruente en relación con la banda sonora" (1992: 61 / TP). 
Para Chion, "el sonido supone de entrada movimiento, contrariamente a lo visual" (1993: 21), y, para Ràfols y Colomer, "implica forzosamente por su naturaleza un desplazamiento, una agitación, que puede tener distintas intensidades; mientras un sonido continuado y sostenido crea poca sensación de actividad, un sonido trepidante y accidentado crea una fuerte sensación de acción" (2006: 34). En consecuencia, según Fandos Igado, la regla básica del videoclip sería el movimiento: "El vídeoclip tiene un odio visceral al estatismo de las imágenes e impone el dinamismo a ultranza, en algunos casos vertiginoso" (1993: 97). Sin embargo, esto no debe plantearse, en modo alguno, como una especie de frenesí sin sentido o, como sugería Kinder (1984: 5), por la influencia de la cocaína. El movimiento que suele mostrar el videoclip a todos los niveles debe entenderse como una metáfora del sonido (Frith, 1988: 216). Y, si se tiene en cuenta que el rock suele tener un tempo rápido, resulta muy sencillo explicar — sin recurrir a extravagantes teorías- por qué el canal MTV ha mostrado siempre, y especialmente en sus inicios, una gran velocidad en la mayoría de sus aspectos.

En segundo lugar, dejando atrás el ritmo y sus elementos derivados, la melodía puede definirse como "un grupo organizado de notas que consta de diversas alturas" (Shuker, 2005: 218). En la música popular, la melodía principal suele identificarse en la voz del cantante solista, aunque puede haber melodías de acompañamiento, cantadas por otros miembros del grupo o coristas, y otro tipo de melodías, como las de bajo (2005: 218). Este elemento musical es el más enigmático de todos, ya que no existen parámetros racionales que permitan aprehenderlo. No en vano, "la idea de la melodía va asociada a la emoción intelectual" (Copland, 1972: 44). Por tanto, aunque pueda percibirse la influencia de una determinada melodía en la configuración formal del videoclip, es difícil establecer una correlación directa, más allá de la sistematización de determinadas relaciones puntuales. Por ejemplo, Vernallis relaciona el contorno de la melodía - esto es, la forma que traza cuando sube y baja- con el movimiento dentro del cuadro (2004: 160) y con la angulación (2004: 33), como sucede en fragmentos de Take a Bow, de Madonna, y November Rain, de Guns N'Roses, respectivamente.

En tercer lugar, los videoclips pueden reflejar diversos aspectos relacionados con la armonía, esto es, "el sonido simultáneo de dos o más notas diferentes al mismo tiempo, como en los acordes de guitarra, los bloques de notas en el piano y el sonido de un coro" (Shuker, 2005: 218). Por ejemplo, suele considerarse que las tonalidades mayores transmiten una sensación de alegría, mientras que las menores tienden a evocar tristeza. En cualquier caso, el reflejo suele ser mayor cuando existen modulaciones o cambios de tonalidad a lo largo de la canción. Así, Vernallis hace referencia a la modulación que suele tener lugar en el último tercio de las canciones pop. Ésta provoca la sensación de subir un peldaño para ubicarse en un plano emocional superior. Dicho ascenso suele reflejarse icónicamente en el en On Bended Knee, de Boyz II Men, con cambios en las combinaciones de colores 
(Williams, 2003: 108), o con una imagen que muestre un clímax visual, como es el caso de la explosión de una bomba atómica en Man in the Mirror, de Michael Jackson.

$\mathrm{Y}$, en cuarto lugar, el timbre es "la cualidad del sonido producido por un determinado agente sonoro" (Copland, 1972: 64). Dicho de otro modo, el timbre nos permite diferenciar un instrumento de otro y una voz de otra, esto es, "dos sonidos iguales en sonoridad, tono y duración, pero de diversa procedencia" (Gértrudix Barrio, 2003: 69). En general, el timbre podría tener una manifestación visual en aspectos como el color, la puesta en escena o los efectos visuales empleados (Williams, 2003: 108). Y, aunque resulte una obviedad, el timbre influye en la medida en que el videoclip suele mostrar los distintos instrumentos y voces que toman parte en la canción, especialmente cuando existe algún solo o un simple fragmento en que un instrumento o una voz adquiere un mayor o menor protagonismo. Este hecho se acentúa cuando el grupo emplea — de forma puntual o permanenteinstrumentos poco frecuentes en su género musical, como es el caso de Mägo de Oz, cuyo violín suele recibir una atención icónica relativamente elevada en sus videoclips, como sucede, por ejemplo, en Fiesta pagana. En el ámbito de la música popular, es particularmente importante el timbre del cantante principal. Por ejemplo, no evoca las mismas imágenes la voz de Tom Waits que la de Mika, ni la de Rocío Jurado que las de Los Pecos.

Aunque se hayan expuesto los cuatro elementos musicales básicos, existen otras cualidades y posibilidades de la música y, en general, del sonido; por ejemplo, el fade in o paso a primer plano, el fade out o desvanecimiento, la reverberación, etc. Éstas pueden ser también representadas por las imágenes, que, en estos casos, "pasan a primer plano y se desvanecen, "fluyen", nos envuelven, e incluso reverberan dentro de nosotros, e imitan las cualidades tímbricas" (Vernallis, 2004: 177 / TP). Asimismo, el empleo de otros recursos propios del sonido, como puede ser el scratching, puede tener también una contrapartida visual. Por ejemplo, en Rockit, de Herbie Hancock, los robots protagonistas del videoclip suelen volver atrás y repetir su movimiento, produciéndose, por así decirlo, un scratching visual.

\section{CONCLUSIONES}

En definitiva, parece claro que la música es un factor clave de cara a la concepción y construcción del videoclip. La función de éste como herramienta de comunicación comercial específica del sector fonográfico y el consecuente hecho de que la música sea preexistente hace que la imagen del videoclip esté fuertemente condicionada por aquélla. 
Esto no quiere decir que el videoclip constituya una mera traducción visual de la música, pero sí que las imágenes son creadas para acompañar visualmente a una canción y, en consecuencia, se ven marcadas por las sensaciones generadas por la música y los distintos elementos que la constituyen. Aunque los estudios tienden a olvidar su importancia, puede decirse que, resumiendo, la música es la base del videoclip y, por tanto, también de sus imágenes. La unión de música e imágenes dará lugar a un conjunto sinérgico que recibe el nombre de videoclip.

\section{REFERENCIAS BIBLIOGRÁFICAS}

ABT, D.: Music Video: Impact of the Visual Dimension. En LULL, J. (ed.) (1987): Popular Music and Communication. Newbury Park: Sage, pp. 98-111.

ARMER, A. A. (1990): Directing Television and Film. Belmont: Wadsworth Publishing Company. AUFDERHEIDE, P.: "Music Videos: The Look of the Sound". Journal of Communication, vol. 36, n. 1 (Marzo 1986), pp. 57-78.

AUSERÓN, S. (1998): La imagen sonora. Notas para una lectura filosófica de la nueva música popular. Valencia: Episteme.

BRUNER II, G. C.: "Music, Mood, and Marketing". Journal of Marketing, vol. 54, n. 4 (Octubre 1990), pp. 94-104.

CHION, M. (1993): La audiovisión. Introducción a un análisis conjunto de la imagen y el sonido. Barcelona: Paidós.

COPLAND, A. (1972): Cómo escuchar la música. México: Fondo de Cultura Económica.

CUBITT, S.: 'Maybellene': Meaning and the Listening Subject. En MIDDLETON, R. (ed.)

(2000): Reading Pop: Approaches to Textual Analysis in Popular Culture. New York: Oxford University Press, pp. 141-159.

DARLEY, A. (2002): Cultura visual digital: Espectáculo y nuevos géneros en los medios de comunicación. Barcelona: Paidós.

DICKINSON, K.: Music Video and Synaesthetic Possibility. En BEEBE, R. \& MIDDLETON, J. (eds.) (2007): Medium Cool: Music Videos from Soundies to Cellphones. Durham: Duke University Press, pp. 13-29.

FANDOS IGADO, M.: "El vídeo-clip musical". Comunica. Revista de medios de comunicación y enseñanza, n. 1 (1993), pp. 96-99.

FERNÁNDEZ-SANTOS, E.: "Los vídeos musicales de Spike Jonze muestran su gran talento visual”. El País, 29/01/2004, p. 37.

FISKE, J.: "Videoclippings". Australian Journal of Cultural Studies, vol. 2, n. 1 (Mayo 1984), pp. 110-114.

- "MTV: Post-Structural Post-Modern". Journal of Communication Inquiry, vol. 10, n. 1 (Enero 1986), pp. 74-79.

- (1997): Television culture. London: Routledge.

FRITH, S. (1988): Music for Pleasure: Essays in the Sociology of Pop. New York: Routledge. GASKELL, E. (2004): Make Your Own Music Video. East Sussex: Ilex.

GÉRTRUDIX BARRIO, M. (2003): Música y narración en los medios audiovisuales. Madrid: Laberinto.

GOODWIN, A. (1992): Dancing in the Distraction Factory: Music Television and Popular Culture. Minneapolis: University of Minnesota Press.

GOW, J.: "Music Video as Communication: Popular Formulas and Emerging Genres". Journal of Popular Culture, vol. 26, n. 2 (Otoño 1992), pp. 41-70.

-"Mood and Meaning in Music Video: The Dynamics of AudioVisual Synergy". Southern Communication Journal, n. 59, n. 3 (1994), pp. 255-261. 
GROSSBERG, L.: The Media Economy of Rock Culture: Cinema, Post-Modernity and Authenticity. En FRITH, S., GOODWIN, A. \& GROSSBERG, L. (eds.) (1993): Sound and Vision: The Music Video Reader. London: Routledge, pp. 185-209.

HAYWARD, P.: Industrial Light and Magic: Style, Technology and Special Effects in the Music Video and Music Television. En HAYWARD, P. (ed.) (1990): Culture, Technology \& Creativity in the Late Twentieth Century. London: John Libbey, pp. 125-147.

JONES, S.: "Seeing Sound, Hearing Image: "Remixing" Authenticity in Popular Music Studies". M/C: A Journal of Media and Culture [en línea], vol. 2, n. 4 (Junio 1999) [Consulta: 15 julio 2008]. <http://journal.media-culture.org.au/9906/remix.php>

KAPLAN, E. A. (1989): Rocking around the clock: music television, postmodernism and consumer culture. London \& New York: Routledge.

KINDER, M.: "Music Video and the Spectator: Television, Ideology and Dream". Film Quarterly, vol. 38, n. 1 (Otoño 1984), pp. 2-15.

LEGUIZAMÓN, J. A. (1998): Videoclips. Una exploración en torno a su estructuración formal y funcionamiento socio-cultural. Informe de investigación inédito, Universidad Católica de Santiago del Estero [Consulta: 1 junio 2006]. <http://www.fortunecity.com/victorian/ bacon/1244/IndiceLegui.html>

LIPOVETSKY, G. (1990): El imperio de lo efímero. La moda y su destino en las sociedades modernas. Barcelona: Anagrama.

LULL, J.: Popular Music and Communication: An Introduction. En LULL, J. (ed.) (1992): Popular Music and Communication. Newbury Park: Sage, pp. 1-32.

MCCLARY, S. \& WALSER, R.: Start Making Sense! Musicology Wrestles with Rock. En FRITH, S. \& GOODWIN, A. (eds.) (1990): On Record: Rock, Pop and Written Word. London: Routledge, pp. 277-292.

OSBORNE, J. W.: "The Mapping of Thoughts, Emotions, Sensations, and Images as Responses to Music". Journal of Mental Imagery, vol. 5, n. 1 (Primavera 1981), pp. 133-136. PÉREZ-YARZA, M. (1996): Videoclip e imágenes del descrédito. Black Hole Sun, de Soundgarden. Valencia: Episteme.

- (1997): El placer de lo trágico. Semiosis del video-rock de los años 90. Tesis doctoral inédita, Universidad del País Vasco.

QUITTNER, A. \& GLUECKAUF, R.: "The Facilitative Effects of Music on Visual Imagery". Journal of Mental Imagery, vol. 7, n. 1 (Primavera 1983), pp. 105-120.

RAE (2003): Diccionario de la Lengua Española. Madrid: Espasa.

RÀFOLS, R. \& COLOMER, A. (2006): Diseño Audiovisual. Barcelona: Gustavo Gili.

ROBINSON, D. C.: "Youth and Popular Music: A Theoretical Rationale for an International Study". Gazette: The International Journal for Communication Studies, vol. 37, n. 1-2 (Febrero 1986), pp. 33-50.

QUITTNER, A. \& GLUECKAUF, R.: "The Facilitative Effects of Music on Visual Imagery". Journal of Mental Imagery, vol. 7, n. 1 (Primavera 1983), pp. 105-120.

RAE (2003): Diccionario de la Lengua Española. Madrid: Espasa.

RUBEY, D.: Voguing at the Carnival: Desire and Pleasure on MTV. En DECURTIS, A. (ed.) (1992): Present Tense: Rock \& Roll and Culture. Durham \& London: Duke University Press, pp. 235-270.

SEDEÑO VALDELLÓS, A. M. (2002): Lenguaje del videoclip. Málaga: Universidad de Málaga. SHORE, M. (1984): The Rolling Stone Book of Rock Video. New York: Quill.

SHUKER, R. (2005): Diccionario del rock y la música popular. Barcelona: Ma Non Troppo.

TETZLAFF, D. J.: "MTV and the Politics of Postmodern Pop". Journal of Communication Inquiry, vol. 10, n. 1 (Enero 1986), pp. 80-91. 
VERNALLIS, C. (2004): Experiencing Music Video: Aesthetics and Cultural Context. Columbia: Columbia University Press.

WELLS, A.: "Popular Music: Emotional Use and Management". Journal of Popular Culture, vol. 24, n. 1 (Verano 1990), pp. 105-117.

"The

Emotional Use of Popular Music by Adolescents". Journalism Quarterly, vol. 68, n. 3 (Otoño 1991), pp. 445-454.

WILLIAMS, K. (2003): Why I [Still] Want My MTV: Music Video and Aesthetic Communication. Cresskill: Hampton Press.

\section{Breve semblanza del autor}

David Selva Ruiz es Doctor por la Universidad de Sevilla y trabaja como docente e investigador en el Departamento de Marketing y Comunicación de la Universidad de Cádiz. Entre sus líneas de investigación destaca el estudio de las herramientas no convencionales de comunicación comercial y, en concreto, del videoclip.

(Recibido el 01-04-2011; aceptado el 22-11-2011) 